\title{
ハイリスク新生児の評価
}

\author{
半 澤 直 美*
}

\section{The Assessment of the Neonatal High-risk Infants}

\author{
Naomi HANZAWA ${ }^{*}$
}

\begin{abstract}
In spite of the advancement of neonatology over the past 25 years, neonatal neurological deficits still occur. Rehabilitation professionals are required to assess neonatal neurological status and screen high risk infants. The indicators to predict developmental outcomes of the high risk infants in the neonatal periods are ; 1) perinatal risk factors, 2) neurological examination, 3) general movements, and 4) neurobehavioral assessment. Severe complications of the central nervous system are risk factors for major neurologic problems. Particularly, periventricular leukomalacia and periventricular hemorrhage are significant predictors of subsequent cerebral palsy. Ultrasound brain scan, CT and MRI have helped in the non-invasive detection of brain damage in young preterm infants. Social class is related to problems in the primary school. The traditional neurological examination consists of the grading of the state, muscle tonus, posture, spontaneous movements, reflexes, and other neurological abnormalities such as neonatal seizures, repeated apnea, oral-motor dysfunction, or high-pitched cry. Qualitative assessment of general movement has been shown to be a good predictor of neurologic outcome in high risk preterm infants. Brazelton Neonatal Behavioral Assessment Scale combines both behavioral and neurological approaches. The following points should be kept in mind when assessing infants in the neonatal period. 1) To predict subsequent disabilities, we must consider findings of various assessment methods comprehensively. 2) The assessment should be designed to be easy, reliable, and non-invasive. 3) Children must be followed up at least until they enter primary schools.
\end{abstract}

Key words : ハイリスク新生児 (neonatal high-risk infants), 危険因子 (risk factor), 神経学的診察 (neurological examination), 発達予後 (development outcome)

\section{はじめに}

近年の新生児医療の発達に伴い, 多くのハイリ スク新生児の生命予後は改善し, 現在はその発達 の質が問われる時代になっている。脳性麻痺や中 等度以上の精神遅滞についてはそのほとんどが乳 児期に診断されて早期療育が開始されているが,
新生児の段階ではその徵候をみつけるのは難しい とされてきた。しかし新生児期に何らかの異常徵 候が特定できるならばその後のフォローアップの 効率化が図れると思われる。

リハビリテーション科（以下，リ八科）が「新 生児評価」を依頼される場合は, 生命予後よりも 発達予後を予測するための評価を期待されている ことがほとんどである。そのためある程度全身状

2000 年 5 月 2 日受稿

* 横浜市北部地域療育センター/テ 224-0062 神奈川県横浜市都築区葛が谷 16-3

Yokohama North Area Rehabilitation Center for Children 
態が安定した状態で紹介されることが多いが，出 産予定日での評価というタイミングを外さないた めには多少不安定な時期でも評価しなければなら ない場合がある。

本稿では, 発達予後を予測するための新生児期 の有効な指標として, (1) 周産期リスク因子およ び画像所見, (2) 神経学的異常所見, (3) general movement, (4)行動学的評価などに注目し, 新 生児評価の流れと現状について述べる.

\section{周産期リスク因子}

周産期の「生物学的リスク因子」と, それ以降 の社会的・経済的状況などの「社会的リスク因 子」が, 発達予後に大きな影響を与えることにつ いては過去多くの報告がある.

\section{1. 生物学的リスク因子}

MRI が普及する以前の報告では, 脳性麻痺や 精神遅滞と関連がある生物学的リスク因子とし て, 出生体重・脳出血・水頭症をあげているもの が多い ${ }^{1 \sim 4)}$. 痸卛・反復性無呼吸・慢性肺疾患・ 長期人工呼吸管理と予後との関連については, 知 見は分かれている ${ }^{3,5 \sim 7)}$. 仮死については予後との 関連ははっきりしないとする報告もあるが6), 重 症仮死で低酸素性虚血性脳症 Hypoxic ischemic enchelopathy（以下 HIE）II期またはIII期とな った例では神経学的後障害を残す割合が高くな $ろ^{3,8)}$.

MRI が普及してくると, 脳室周囲白質軟化症 Periventricular leukomalacia（以下 PVL）と脳 室周囲出血 Periventricular hemorrhage（以下 PVH）が脳性麻痺のリスク因子として大きな注 目を浴びるようになった ${ }^{9)}$. PVH は, 脳室周囲 白質の出血性壊死であり, 脳室内出血 Intraventricular hemorrhage（以下 IVH）に合併して起 こると考えられており，ほとんどが非対称的であ る ${ }^{9)}$. 症状は㾏性片麻痺か非対称な四肢麻痺を示 す.急性期の PVH を確認するには頭部超音波検 査が適当であるが，慢性期に損傷の広がりを調べ 予後を推定するには MRI が有用である. PVL
は未熟児の脳室周囲白質に生じる虚血性病変で, 多くは対称的である ${ }^{9)}$. 上肢より下肢に強い痤性 麻痺を特徴とし, 病巣の広がりによっては視覚認 知の障害との関連も注目されている ${ }^{10)}$. 囊胞を形 成していない場合は超音波検査では見つけにくく MRI が最も有用な検査である.

\section{2.リスク因子と予後予測}

リスク因子だけで予後を予測することは問題が ある. Kitchen ${ }^{11)}$ は 2 つの病院の極低出生体重児 252 人を対象に, 脳性麻痺と精神遅滞のリスク因 子について両院の比較を行った。 そして予後と相 関を認めたリスク因子のうち，両院に共通するも のはなく,「脳性麻痺を予防するための治療を行 う適応基準はない」と結論している. 過去の研究 で, 統計学的に有意な予後予測因子であるとされ た合併症を持っていても, 実際の臨床場面で「こ の児が脳性麻痺になるかどうか」は可能性の程度 でしか示すことはできない. 周産期りスク因子の 評価は, それ単独で評価することよりも, 診察や 経過観察の参考とすることで意義が出てくると思 われる。

\section{3. 社会的リスク因子と minor handicap}

発達予後を考えるとき, いわゆる major handicap (脳性麻痺・精神遅滞・てんかん・重度の視 力障害や聴力障害）だけではなく, minor handicap（学習障害・注意欠陷多動性障害など）も注 目されてきている。極低出生体重児が, 学童期に 特別な教育的配慮を必要とする割合については, $48.8 \sim 64 \% \%^{3,12 \sim 15)}$ との報告がある. Hunt ${ }^{16)}$ は, 重度の障害を持たない極低出生体重児 108 名につ いて 8 歳時に WISC-R および B-G testを施行し た. 全体の $81.5 \%$ IQ が 85 以上であったが, そのうち $56 \%$ VIQ と PIQに 15 以上の差があ るかまたは FIQ と B-G のスコアに差がみられる など偏ったパターンを示していた. Whitfield ${ }^{17)}$ も, 超低出生体重児では, IQ 85 以上でも学習障 害の頻度が 3 倍であったとしている. 極低出生体 重児の学童期の問題として, 算数と読解が特に弱




動の障害 ${ }^{12,18)}$, 注意欠陥多動性障害19) などがあげ られている。このようないわゆる minor handicapにおける新生児期リスク因子についても多く の報告がある. Msall ${ }^{3)}$ は, 生物学的リスク因子 は major handicap と関連があり，社会的リスク 因子は「教育上の障害」と関連があるとし, Hunt $^{16)}$ は, 生物学的リスク因子は学童期の「教 育上の障害」の有無に影響し, 社会的リスク因子 はその障害の程度に影響すると述べている。また 神経学的な異常の予測がほぼ 1 歳くらいで可能 なのに対し, これらの minor handicapが予測 可能となる時期は 4 7 歳とやや遅い傾向があ $る^{13,14)}$. Weisglas-Kuperus ${ }^{20)}$ は, 生物学的リス ク因子は 1 歳時の予後と, 社会的リスク因子は 2 歳以降の予後の良い指標になるとし, 生物学的リ スクの高低にかかわらず，良い刺激が受けられる 家庭環境の有無はその後の認知能力の発達に影響 を及湾すと述べている。

\section{新生児の神経学的診察法}

古典的な神経学的診察法として, Thomas ${ }^{21)}$, Amiel-Tison ${ }^{22)}$, Prechtl ${ }^{23)}$, Dubowitz ${ }^{24)}$ の紹介 した方法がよく知られている。これは意識状態・ 筋緊張・姿勢・原始反射・神経学的異常徴候（新 生児㾏卛・無呼吸発作の頻発・哺乳障害・異常啼 泣など）を組み合わせたもので，脳障害の急性期 や，脳障害が重度である場合などには有効な方法 であるが，一方で，このように全身状態が不良で 集中的治療を行っている児に対しては十分な評価 を行うのが困難であるという問題があった。ま た，近年の画像診断技術の発達によって古典的な 神経学的診察法は診断的価值という点からはあま り重視されなくなってきた。


学的評価は, 評価時期は予定日前後とし, 反応を 評価する時の「状態」 state の重要性を強調して いる.そして各反応を正常からの逸脱の大きさで 評価し, 異常パターンを 3 群に分けた。この評価 法は系統的でわかりやすいものだが，検者の経験 と技術に頼るところが大きいという難点があり，
これが予後予測性の悪さにつながっている. Dubowitz ${ }^{24)}$ は，予定日前の未熟児にも使用で き, 出生直後から継時的に変化を追える評価表を 示した。これは特別な知識・技術を要さない簡便 で客観的な評価法であり，10〜15 分で行えるた めルーチンの評価としても使用できる.

このような神経学的診察法をもとにして様々な 評価法が報告されてきた。 Knobloch ${ }^{25)}$ は 88 人 の極低出生体重児を新生児期に評価し, 正常とし た児の $96 \%$ は正常発達したのに対し, major handicap を予想した児で正常発達したのは $20 \%$ であり，65\%は脳性麻痺または精神遅滞となって いた。脳性麻痺になった群の麻痺型を調べてみる と, 㾏直型を予測した全例は痤直型であったが, 低緊張型を予測した 3 例では 2 例が正常化してい た. Dubowitz ${ }^{26)}$ も 124 人の未熟児を評価し, 正 常と予測した児の $91 \%$ は正常発達し，発達障害 を予測した児で正常発達したのは $35 \%$ であった。 また異常徵候の有無のみよりも，頭部超音波検査 と組み合わせたほうが予測能力は改善することを 示した. 超音波検查上の異常所見としては, 脳室 周囲の高輝度・エコー透過像（囊胞）・脳室拡大 の持続などがあげられる. Stewart ${ }^{27)} も$ 頭部超音 波検査を組み合わせれば，正常と予測した児の 98\%が正常発達したことを報告している．Morgan $^{28)}$ は, Thomas ${ }^{21)}$ や Brazelton ${ }^{29)}$ や Dubo$w_{i t} z^{24)}$ の評価表を参考に, 27 項目（筋トーヌ ス・運動パターン・原始反射・行動反応）から成 る独自の評価表を作成して 298 人のハイリスク児 と 54 人の満期産正常児の評価を行い, 評者間の 一致率が高いことを示した. Scheiner ${ }^{30)} も, 18$ 項目のリスク因子と 5 項目の神経行動学的評価 ・ 17 項目の教育環境因子から成る独自の評価表を 作成してハイリスク新生児 125 人を評価し, 発達 障害を予測する上で高い感受性と特異性を持つこ とを示した。

\section{General Movement}

従来, 新生児の運動は, 原始反射や姿勢に伴う 反応で説明されてきた.しかし覚醒状態で機嫌の 
良い新生児は，刺激がなくても四肢をランダムに 動かしている.Precht1 ${ }^{31}$ は は反射や姿勢反応だけ では説明できない自発運動 spontaneous movement が胎児や新生児の運動の主体であるとし, general movement（以下 GM）に注目した。

GM とは，四肢のいずれかの部分から始まり数 十秒から数分続く全身の粗大運動であり, 運動の 間にその大きさ・方向・速度が変化し, その動き は滑らかさ・優雅さ・複雑さ・多様性などの特徵 を持つ. また後の随意運動の発達とは異なり, 始 めから全身を使った運動であり，そして反射のよ うに特定の刺激によって誘発されるものではな い. 自発運動は反射・反応よりも神経系の異常の 影響を受けやすいと考えられることから，GM は 障害のより鋭敏な指標になり得る.

GM の評価は, 覚醒状態の仰臥位の新生児を入 院中は 1 2 時間, 外来では $10 \sim 15$ 分間ビデオテ ープに記録して行う. GM の評価の利点は，児の 自然のままの状態の運動評価であるため, 抻管し ている重症児にも安全に行え, ビデオ録画するこ とによって何度でも複数の人間が評価できるとい う点である. Precht1 ${ }^{31)}$ は複数の検者間の評価結 果の一致率が高いことを示した。

観察項目は, 運動の大きさ・速度・始まり方と 終わり方・性質・優雅さと滑らかさ・指の運動で ある. Ferrari ${ }^{32)}$ は, GM の量的・質的徵候を体 系的に分析する方法を示した。

正常新生児と脳損傷児の自発運動を比較する場 合, (1)量的な違い, (2)質的な違い, (3)継時的変化 の違い, の 3 点から考える必要がある. 質的な違 い（運動の優雅さや滑らかさの減少, 運動の強 さ・方向・速度の多様性の減少, 定型的な動き) を認めたとの報告は多いが32 34), 量的な違いに

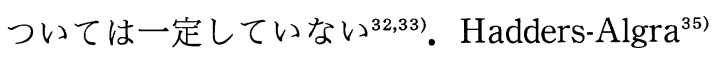
は, 脳障害を持つ新生児の GM のパターンを観 察と表面筋電図によって，(1) mildly abnormal GM（運動の複雑性は保たれているが滑らかさに 欠ける), (2) definitely abnormal GM (運動の 複雑さ・滑らかさともに欠ける）に分類した。

継時的な変化に付いては, 小西 ${ }^{36)}$ が胎児期か ら新生児期の運動の連続性について以下のように
述べている. 受精後 8 週ころより出現した胎動 は, 20 週にはすべての運動がみられるようにな り新生児期まで続く．生後 1 カ月ころより，その 種類によって消失したり持続したり，または一時 消失して再び出現するなど様々な変化を示す. 生 後 2 力月は乳児の行動が大きく変化する時期であ り (the two month revolution), 胎動のパター ンが消失し $4 \sim 6$ カ月以降の新たな随意運動がみ られはじめる転換点となる。

これら一連の経過の中で年齢に応じ GM は， preterm $\mathrm{GM} \cdot$ writhing $\mathrm{GM} \cdot$ fidgety $\mathrm{GM}$ と変 化し, 表面筋電図による研究ではこれらの変化は 筋肉の収縮活動の大きさの減少・活動時間の短縮 として示され，より完成されたスムーズな運動へ

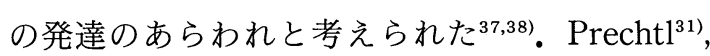
Hadders-Algra $^{35)}$ はこの変化の過程が脳障害に よって大きく影響を受けることを見出し，多賀 ${ }^{39)}$ は，脳障害では GM のパターンが単純化し，月 齢に応じた変化がないと述べている。

また発達学的な予後予測においても GM が有 用であるとの報告がある。Cioni ${ }^{40)}$ は, GM は画 像診断と同じ程度に正確で, 神経学的診察法より も有用であったと述べている，痙性両麻痺児の一 部は予定日での神経学的評価では異常性を示さな いが,より複雑な統合の現われである GM の評 価においてはf false-negativeが少なかった. Fer$\operatorname{rari}^{32)}$ は, 頭部超音波検査上の異常の有無によっ て未熟児を低リスク群と高リスク群に分けて GM の比較を行い, 低リスク群の 93\%は正常パター ンであったが高リスク群の $100 \%$ は質の異常を示 したと報告した. Hadders-Algra ${ }^{35)}$ は, 胎齢 39 週以前の GM は頭部エコー所見と関連し, 修正 7 週以降の GM は神経学的予後と強く関連すると した. GMの経過と予後については, fidgety

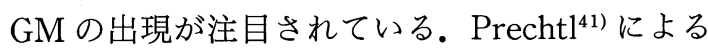
と fidgety GM が正常であった児の $96 \%$ は正常発 達し, 異常または欠如していた児の 95\%は後に 神経学的異常を示した. Hadders-Algra ${ }^{42)}$ は, fidgety GM で mildly abnormal であった児は, 注意欠陥多動性障害 ADHD を含む軽度の神経学 的機能障害を示すリスクが高く, definitive 
abnormal であった児は，脳性麻痺になるリスク が高いとした．さらに幼児期の行動障害などの問 題は，GM および社会的リスク因子と関連があ り，神経学的評価との関連は薄いとした。一方 Geerdink ${ }^{43)}$ は, 予後予測能力が 12 週以降に改善 することから，この時期に神経機能の大きな変化 が起こっている可能性を示唆した。

\section{新生児行動評価}

新生児期の行動発達という点から新生児を評価 する試みも古くから行われてきた。 Brazelton ${ }^{29)}$ は, 刺激に対する新生児の行動反応や, 新生児が 外界からの刺激を状態（state）の変化や慣れに よってコントロールする能力を評価し, 新生児行 動評価 Neonatal behavioral assessment scale （以下NBAS）を著した. NBAS は, 行動学的 評価と神経学的評価から成る。䅖山到 は，ハイ リスク新生児を対象にNBASを用いた評価を行 い, 正常発達・脳性麻痺・精神遅滞の判別が高い 精度で可能であることを示した。

\section{新生児評価とリスク因子に関する 自験例からの考察}

新生児期の臨床所見およびリスク因子と，発達 予後との関連については, 第 36 回日本リ八医学 会学術集会にて発表した。神奈川県立こども医療 センターリ八科に紹介される新生児は, 極低出生 体重児は全例，さらに新生児科医が発達上ハイリ スクであると判断した児である。1995 年 9 月か らの 1 年間に紹介された 127 例中，修正在胎

表 1 出生体重別予後（修正 2 歳時点）

\begin{tabular}{lccc}
\hline & $1,500 \mathrm{~g}$ 未満 & $1,500 \mathrm{~g}$ 以上 & 計 \\
\hline 正常範囲 & 29 名 & 24 & 53 \\
境域 & 6 & 1 & 7 \\
脳性麻㾇 & 5 & 2 & 7 \\
発達遅滞 & 3 & 1 & 4 \\
その他 & 5 & 2 & 7 \\
死亡 & 2 & 0 & 2 \\
不明 & 5 & 2 & 7 \\
\hline \multicolumn{1}{c}{ 計 } & 55 & 32 & 87 \\
\hline
\end{tabular}

38〜42 週に評価できた 87 例を対象とした。臨床 所見については, Prechtl の著書 ${ }^{23)} よ り$, (1)眼球 運動，(2)被刺激性，(3)姿勢，(4)運動，(5)筋トーヌ ス，(6)反射・反応，(7)哺乳，の 7 分野 40 項目を 選んでチェックリストを作成し，それに基づいて 診察を行った。リスク因子については，NICU 入院中のカルテより，一般に発達上のリスク因子 とされる診断名を選び記録した。修正 2 歳を過ぎ た時点での予後は表 1 のとおりであった。仮に 「境界域」としたのは，(1)発達指数 70〜79, (2)明 らかな神経学的異常はないが, 軽度の筋緊張の異 常があり経過観察が必要なもの，(3)視力障害・聴 力障害の疑い, (4)軽度の言語発達遅滞，などであ る.「発達遅滞」の 4 例は, 発達指数が $20 \sim 53$ で 将来的に精神遅滞の可能性がある児である。

予後と関連のみられたリスク因子は，脳性麻痺 については新生児痙攣・PVL・HIEであり，発 達遅滞については慢性肺障害（在宅酸素療法また は気管切開となったもの）であった。特にPVL は 5 例全例が脳性麻痺になっていた。

臨床上の異常所見で予後と関連のあったのは, 脳性麻痺では固視・追視なし, 異常眼球運動, frog posture, 上肢運動範囲の狭小，肩の後退， 下肢の緊張元進，引き起こしでの「そり」の 7 項 目で, 発達遅滞では, 引き起こしでの「頭部の遅 れ」の 1 項目であった.

図 1 は，評価した 40 項目中，異常を示した項 目数を正常群と脳性麻痺群について比較したもの である．正常群では 53 例中 52 例（98\%）が 4 項 目以下であったが，CP群では 4 項目以下は 9 例 中 2 例 $(22 \%)$ であった。この 2 例は新生児期に は神経学的異常徴候に乏しかったが，いずれも入 院中の頭部 MRI で PVL を指摘され両親にはそ の時点で脳性麻痺の可能性について説明がなされ ていた。これらより，新生児期に臨床上の異常所 見に乏しい場合も，画像所見や病歴上のリスク因 子なども合わせて総合的に考えることによって， かなりの程度脳性麻痺の可能性については予測が つくものと思われた，そしてこれは，その後のフ オローアップの効率化や，訓練開始および療育施 設紹介時期の判断をするうえでの助けになると考 


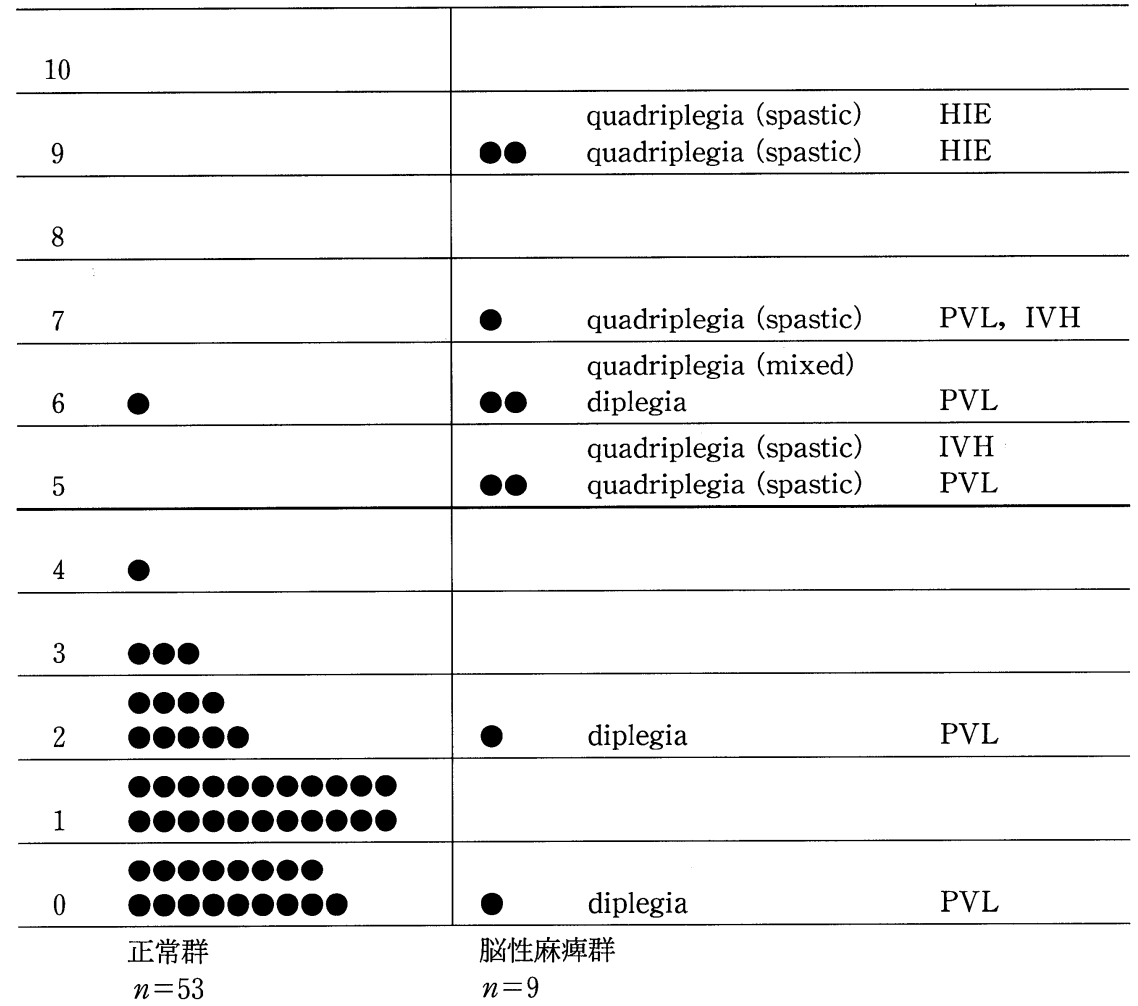

図 1 新生巟評価における異常項目数の比較

は 1 症例を示す. 脳性麻痺群は各症例の右に麻痺型と麻痺の原因を示した。

\section{えられる。}

この調査では予後の判定を行った時期が修正 2 歳という早い時期であったため，今回「境界域」 または「正常」と判断した览の中からも，将来軽 度の脳性麻痺やボーダーレベルの精神遅滞・学習 障害などを指摘される児が出てくる可能性も高 い. 最終的な予後判断を行うためには, 小学校中 学年までは追跡する必要があると思われる.

この研究で用いたチェックリストは, 予後判定 のための標準化された評価表ではない. 今後フォ ローアップの効率化などの目的で関連部門で共通 して用いることを考えるならば，信頼性や妥当性 について十分検討された評価表の作成が望まれ る.

$$
\text { ま と め }
$$

1）発達予後を予測するための新生児期の指標 として, 周産期リスク因子および画像所見・神経 学的評価・GM・行動学的評価などがあるが, 1 つの評価だけでなくこれらを組み合わせて総合的 に判断することがより正確な予後予測につながる と思われる。

2）極低出生体重児の予後については，いわゆ る minor handicapも注目されてきており，最終 的な予後判定には小学校中学年までフォローアッ プを行う必要がある。

3）新生児は全身状態が不安定であったり，治 療・処置や検査による診察の制限も多いことか ら，評価法は児への負担の少ない簡便なものが望 ましい.また新生児科医との信頼関係を築くため 
には，評価法も客観的で信頼性・妥当性に優れた ものを用いていく必要がある.

\section{文献}

1) Pape KE, Buncic RJ, Ashby S, Fitzhardinge PM : The status at two years of low-birth-weight infants born in 1974 with birth weight of less than $1001 \mathrm{gm}$. J Pediatr 1978; 92: 253-260

2) Knobloch H, Malone A, Ellison PH, Stevens F, Zdeb $\mathrm{M}$ : Considerations in evaluating changes in outcome for infants weighing less than 1501 grams. Pediatrics $1982 ; 69$ : 285-295

3) Msall ME, Buck GM, Rogers BT, Merke D, Catanzaro NL, Zorn WA : Risk factors for major neurodevelopmental impairments and need for special education resources in extremely premature infants. J Pediatr 1991; 119 : 606-614

4) Campbell MK, Halinda E, Carlyle MJ, Fox AM, Turner LA, Chance GW: Factors predictive of follow-up clinic attendance and developmental outcome in a regional cohort of very low birth weight infants. Am J Epidemiol 1993; 138 : 704-713

5) Rothberg $\mathrm{AD}$, Maisels $\mathrm{MJ}$, Bagnato S, Murphy J, Gifford K, Mckinley K: Infants weighing 1000 grams or less at birth: developmental outcome for ventilated and nonventilated infants. Pediatrics $1983 ; 71: 599-602$

6) Stanley FJ, English DR: Prevalence of and risk factor for cerebral palsy in a total population cohort of low-birth weight $(<2000 \mathrm{~g})$ infants. Dev Med Chil Neurol 1986; 28 : 559-568

7) Hack M, Taylor HC, Klein N : School-age outcomes in children with birth weights under $750 \mathrm{~g}$. N Eng J Med 1994 ; 331 : 753-759

8）三科 潤：ハイリスク児の神経学的予後. 小児科診療 $1999 ; 62:$ 1934-1943

9) Volpe JJ : Brain injury in the premature infants. Clinics in perinatology $1997 ; 24: 567-587$

10）小寺澤敬子, 下垣佳代子, 鍋谷まこと, 宮田広善, 児玉 荘一: 視知覚認知障害を認める㾏直型両麻盘児の VEP, SSEP 所見. 脳と発達 1996；28：261-263

11) Kitchen WH, Yu VYH, Orgill AA, Ford G, Rickards A, Astbury J, Lissenden JV, Bajuk B: Collaborative study of very-low-birth-weight infants. Am J Dis Child 1983; 137 : 555-559

12) Nickel RE, Bennett FC, Lamson FN : School performance of children with birth weights of $1000 \mathrm{~g}$ or less. Am J Dis Child 1982; 136 : 105-110

13) Sell EJ, Gaines JA, Gluckman C, Williams E: Early identification of learning problems in neonatal intensive care graduates. Am J Dis Child 1985; 139 : 460-463

14) Vohr BR, Garcia Coll CT: Neurodevelopmental and school performance of very low-birth-weight infants: a seven-year longitudinal study. Pediatrics $1985 ; 76: 345-350$
15) Eilers BL, Desai NS, Wilson MA, Cunningham MD : Classroom performance and social factors of children with birth weights of 1250 grams or less: follow-up at 5 to 8 years of age. Pediatrics 1986; 77: 203-208

16) Hunt JV, Cooper BAB, Tooley WH: Very low birth weight infants at 8 and 11 years of age: role of neonatal illness and family status. Pediatrics $1988 ; 82: 596-603$

17) Whitfield MF, Eckstein RV, Holsti L: Extremely premature $(<800 \mathrm{~g})$ school children: multiple areas of hidden disability. Arch Dis Child 1997; 77 : $85-90$

18) O'Callaghan MJ, Burns YR, Gray PH : School performance of ELBW chidren: a controlled study. Dev Med Child Neurol 1996 ; 38 : 917-926

19) Botting N, Powls A, Cooke RWI : ADHD and psychiatric outcome in very low birth weight children at 12 years. J Child Psychol Psychiat 1997; 38 : 931-941

20) Weisglas-Kuperus N, Baerts W, Smrkovsky M, Sauer PJJ : Effects of biological and social factors on the cognitive development of very low birth weight children. Pediatrics $1993 ; 92$ : 658-665

21) Thomas A, Chesni $Y$, Saint-Anne Dargassies S: The neurological examination of the infant. Spastics International Medical Publications, London, 1960

22) Amiel-Tison C: Neurological evaluation of the maturity of newborn infants. Arch Dis Childhood $1968 ; 43: 89-98$

23) Prechtl HFR: The neurological examination of the full-term newborn infants. in Clinics in Developmental Medicine, 2nd Ed, No. 63, 1977

24) Dubowitz LMS: The neurological assessment of the preterm and full-term newborn infants. in Clinics in Developmental Medicine No. 79, 1981

25) Knobloch $\mathrm{H}$, Malone A, Ellison PH, Stevens F, $Z$ deb $\mathrm{M}$ : Considerations in evaluating changes in outcome for infants weighing less than 1501 grams. Pediatrics $1982 ; 69$ : 285-295

26) Dubowitz LMS, Dubowitz V, Palmar PG, Miller G, Fawer CL, Levene MI : Correlation of neurologic assessment in the preterm newborn infant with outcome at 1 year. J Pediatr $1984 ; 105$ : 452-456

27) Stewart A, Hope PL, Hamilton P, Costello AML, Baudin J, Bradford B, Amiel-Tison C, Reynolds EOR: Prediction in very preterm infants of satisfactory neurodevelopmental progress at 12 months. Dev Med Child Neurol 1988; 30 : 53-63

28) Morgan AM, Koch V, Lee V, Aldag J : Neonatal neurobehavioral examination. A new instrument for quantitative analysis of neonatal neurological status. Phys Ther 1988 ; 68 : 1352-1358

29) Brazelton TB: Neonatal behavioral assessment scale, in Clinics in Developmental Medicine, 3rd Ed, No. 137, 1995 
30) Scheiner AP, Sexton ME: Prediction of developmental outcome using a perinatal risk inventory. Pediatrics 1991 ; 88: 1135-1143

31) Prechtl HFR : Qualitative changes of spontaneous movements in fetus and preterm infant are a marker of neurological dysfunction. Early Hum Dev 1990 ; 23 : 151-158

32) Ferrari F, Cioni G, Prechtl HFR: Qualitative changes of general movements in preterm infants with brain lesions. Early Hum Dev 1990 ; 23 : 193231

33) Prechtl HFR : Motor behaviour of preterm infants. in Clinics in Developmental Medicine, No. 94, 1984 ; pp 79-92

34) Touwen BCL: Variability and stereotypy in normal and deviant development. Clinics in Developmental Medicine, No.67, 1978; pp 99-110

35) Hadders-Algra M, Klip-Van den Nieuwendijk AWJ, Martijn A, van Eykern LA : Assessment of general movements : towards a better understanding of a sensitive method to evaluate brain function in young infants. Dev Med Child Neurol 1997 ; 39 : 89-99

36）小西行郎：未熟児・新生児の自発運動. 日本新生児学 会雑誌 $1998 ； 34 ： 728-733$

37) Hadders-Algra M, Van Eykern LA, Klip-Van den
Nieuwendijk, Prechtl HFR : Developmental course of general movements in early infancy. II. EMG correlates. Early Hum Dev 1992； 28 : 231-251

38）小西行郎: 新生児行動からみた神経異常のスクリーニ ング. 周産期医学 $1998 ; 28 ： 619-623$

39）多賀厳太郎: 複雑系から見た行動発達のダイナミク ス. Neonatal Care $1999 ; 12$ : 117-121

40) Cioni G, Ferrari F, Einspieler C, Paolicelli PB, Barbani MT, Prechtl HFR: Comparison between observation of spontaneous movements and neurologic examination in preterm infants. $\mathrm{J}$ Pediatr 1997 ; 130 : 704-711

41) Prechtl HFR, Einspieler C, Cioni G, Bos AF, Ferrari F, Sontheimer D : An early marker for neurological deficits after perinatal brain lesions. The Lancet 1997 ; 349 : 1361-1363

42) Hadders-Algra M, Groothuis AMC: Quality of general movements in infancy is related to neurological dysfunction, ADHD, and aggressive behaviour. Dev Med Child Neurol 1999 ; 41 : 381-391

43) Geerdink JJ, Hopkins B: Qualitative changes in general movements and their prognostic value in preterm infants. Eur J Pediatr 1993 ; 152: 362-367

44）䅖山富太郎：新生児期の脳性麻痺の諸マーカーと超早 期療育. リ八医学 $1999 ; 36: 91-94$ 